\title{
EFFECT OF DAMAGE CAUSED BY SITE MATERIALS ON THE PERFORMANCE OF NONWOVEN GEOTEXTILES IMPREGNATED WITH ASPHALT EMULSIONS USED
}

ON PAVING

\author{
Mateus A. Lima ${ }^{1}$, Jefferson Lins da Silva ${ }^{1}$, and Maria L. C. Lopes ${ }^{2}$ \\ ${ }^{1}$ São Carlos School of Engineering (EESC), University of São Paulo (USP), São Carlos, São Paulo, Brazil. \\ ${ }^{2}$ University of Porto (UP), Porto, Portugal. \\ ${ }^{1}$ Corresponding author. Contact details: Av. Trabalhador São Carlense, $\mathrm{n}^{\circ}$ 400, Laboratório de Geossintéticos, \\ Departamento de Geotecnia, São Carlos, São Paulo, Brazil (CEP: 13.566-590); e-mail: mateuslima@usp.br
}

\begin{abstract}
A rehabilitation technique for asphalt pavements with geosynthetic is the application of impregnated nonwoven geotextiles between deteriorated and new asphalt overlays. The performance investigation of impregnated geotextiles proves that they are enhancing in mechanical and hydraulic properties. Although, the installation process may cause severe impacts on these materials' performance. During the installation, the geotextile suffers damage due to the traffic of high load vehicles, as compactors and pavers, and the friction with granular materials found under its layer or poured above it. This paper aims to investigate how the damage caused by granular materials on nonwoven geotextiles impregnated with different asphalt emulsions effect on their strength resistance and permittivity. From two types of nonwoven geotextiles: polypropylene and polyethylene terephthalate, the comparison uses geotextiles in three conditions: not impregnated, impregnated with asphalt emulsion of rapid setting, and impregnated with asphalt emulsion changed by an elastomeric polymer. Part of the samples followed the damage according to ISO 10722 procedure, placed between three different scenarios of granular materials, applying gravel, sand, and clay. After the damage process, the samples were submitted to mechanical and hydraulic properties evaluations.
\end{abstract}

\section{KEYWORDS}

Geotextiles. Impregnation. Damage simulation.

\section{INTRODUCTION}

Some techniques for rehabilitation of pavements consider inserting new layers of asphalt overlay to a damaged overlay. These techniques aim to regularize the surface to improve vehicle 
adherence and comfort for users but always looking for increasing structural capacity. In contrast, on the interface between new and cracked overlays may occur propagation of old cracks to the new asphalt overlay. This effect of crack propagation happens due to a high concentration of tensile stresses on the new layer caused by underlayer cracks. Geosynthetics are commonly used as anticrack propagation systems, where they are accountable for reducing the intensity and deviating cracks. Different studies (Norambuena-Contreras \& Gonzalez-Torre, 2015; Zornberg, 2012) point out the geosynthetics used on paving according to the most used, as nonwoven geotextiles, woven geotextiles, and geogrids. The difference between applying geogrids or geotextiles is on how the selected material works, geogrids reduce the shear forces while geotextiles deviate and retard cracks propagation (Cleveland, Button, \& Lytton, 2002; Dhakal, Elseifi, \& Zhang, 2016; Fallah \& Khodaii, 2015; Khodaii, Fallah, \& Nejad, 2008). The anti-crack propagation systems can use nonwoven geotextiles impregnated with asphalt cement offering better adherence between layers due to the cement characteristic.

Considering this, Zamora-Barraza et al. (2011), Norambuena-Contreras and Gonzalez-Torre (2015) studied the interaction of geotextiles and geogrids to pavement layers structure and pointed how it delays cracking reflection on damaged asphalt pavements. Cleveland, Button, and Lytton (2002) said that the enhance of pavements performance with geosynthetics on asphalt overlays occurs as a result of strength increase that this technique provides to the structure. The geosynthetics are applied on pavements with same features used on paving, like pavers and compactors, although the geotextiles are much more sensible than paving materials and can be damaged during this phase, what influence on geosynthetics properties. During the installation of geosynthetics on asphalt overlays, some problems may occur as separation of the binder, geotextile and/or other layers caused by traffic of compactors; reduction of geotextile thickness caused by compaction; and, the friction of the adjacent layers materials can damage the geotextile. This damage caused during installation measured according to ISO 10722:2007 named as damage caused by granular material. 
The ISO 10722 consists of applying a sample of the geosynthetic, between two layers of granular material, to two different load applications approach: one cyclic and one monotonic of reference. The relation between the property measured on the two samples is the effect of the damage during installation; a comparison with the virgin material can also be evaluated. This effect is considered during the design by a reduction factor calculated from the relation between the evaluated samples.

To correctly design the alternative for pavement rehabilitation is important to consider the damages that the geosynthetic will face since its installation and during service lifetime. The designing process considers all the properties of the materials as its ultimate state of use, to calculate correctly the properties are reduced using reduction factors of their properties. The reduction factors are relevant to consider safety when designing properly increasing the time of service of the desired solution. Koerner (2005) considers reduction factors modifying ultimate values properties to allowable values; for paving fabrics, reduction factors stand between 1.1 and 2.0. The equation, as presented by Koerner (2005), can consider as much simulating tests as the laboratory run, according to the final application function. In Equation 1, the reduction factor measured for installation damage, creep, and chemical and biological degradation are considered, as these factors influence tensile strength (Koerner, 2005). The reduction factor for installation damage $\left(R F_{I D}\right)$ is the relation between the ultimate strength of undamaged and damaged samples, respectively.

$$
T_{\text {allow }}=\frac{T_{\text {ult }}}{R F_{I D} \times R F_{C R} \times R F_{C B D}}
$$

The material specified to perform ISO 10722:2007 is a sintered aluminum oxide, even though, some studies have been run using natural granular materials to simulate with a material similar to what is met on field sites (Dias, Carneiro, \& Lopes, 2017; Gonzalez-Torre, Calzada-Perez, VegaZamanillo, \& Castro-Fresno, 2014; Hufenus, Rüegger, Flum, \& Sterba, 2005; NorambuenaContreras, Gonzalez-Torre, Fernandez-Arnau, \& Lopez-Riveros, 2016; Paula, Silvano, Pinho-Lopes, 
\& Lopes, 2004). Some authors (Hufenus et al., 2005; Norambuena-Contreras and Gonzalez-Torre, 2015; Paula et al., 2004; Pinho-Lopes and Lopes, 2014) point out the changes on properties of geosynthetics submitted to this method of damage during installation simulation, although these studies have not considered geotextiles impregnation.

As nonwoven geotextiles are applied on asphalt overlays, it is highly recommended a tack coat impregnation to provide adherence to the interface, and the most common material for tack coat services of flexible pavements is asphalt emulsion (Wang, Xiao, Chen, Li, \& Amirkhanian, 2017). Studies from Correia and Zornberg $(2014,2016,2018)$ focus on the adherence of the binder and on the estimative of the appropriate amount of binder to maximize the benefits of impregnation. Although, there is not a consensus if the asphalt emulsion used to supply adherence between cracked overlay, geotextiles and new overlay damages the geosynthetic structure.

This paper analyzes the tensile properties and permittivity of nonwoven geotextiles used on paving techniques, after impregnation with asphalt emulsion and laboratory damage. The analysis compared PET and PP geotextiles impregnated or not with an emulsion asphalt, CRS-1 or CRS-1S. The laboratory damage simulation applied three granular materials (gravel, sand, and clay) under the geotextile samples and the same granular material (gravel) over them. With tensile and permittivity results the analysis compares the results of all samples. Also, reduction factors determine the variation of properties to consider on designing of rehabilitation techniques.

\section{MATERIALS AND METHODS}

\subsection{Geotextiles}

The geotextiles were chosen according to what is used in paving applications, also considering that geotextiles greater than $180 \mathrm{~g} / \mathrm{m}^{2}$ present poor impregnation (Vilchez, 2002). So, the geotextiles presented here are a polyethylene terephthalate (PET) nonwoven geotextile and a polypropylene (PP) nonwoven geotextile, both with $150 \mathrm{~g} / \mathrm{m}^{2}$ of nominal mass per unit area. The extraction of geotextiles 
specimens from the fabricant sample occurred according to ASTM D4354. The damage specimens measured $60 \mathrm{~mm}$ in the machine direction by $40 \mathrm{~mm}$ in the cross-machine direction of fabrication. The geotextiles parameters considered for this study are in Table 1, the interval with $95 \%$ of the confidence level is defined in brackets.

Table 1 - Technical characteristics of nonwoven geotextiles.

\begin{tabular}{llcc}
\hline Property & Specification & PET & PP \\
\hline Mass per unit area $\left(\mathrm{g} / \mathrm{m}^{2}\right)$ & ASTM D5199 & $143.5( \pm 5.03)$ & $147.3( \pm 3.07)$ \\
Nominal thickness $(\mathrm{mm})$ & ASTM D5261 & $1.58( \pm 0.02)$ & $1.97( \pm 0.04)$ \\
Tensile Strength $(\mathrm{kN} / \mathrm{m})$ & ASTM D5035 & $5.14( \pm 0.33)$ & $6.14( \pm 0.89)$ \\
Strain at break $(\%)$ & ASTM D5035 & $60.32( \pm 1.09)$ & $77.96( \pm 7.6)$ \\
Permittivity $\left(\mathrm{s}^{-1}\right)$ & ASTM D4491 & $5.23( \pm 0.17)$ & $2.31( \pm 0.3)$ \\
\hline
\end{tabular}

\subsection{Asphalt emulsions}

For the impregnation procedure, after a survey with geosynthetic manufacturers and paving companies, two cationic asphalt emulsions of rapid setting have been selected: one unmodified (CRS1) and one with the elastomeric polymer modifier SBS (CRS-1S). Table 2 presents the characteristics of the asphalt emulsions used.

Table 2 - Technical characteristics of asphalt emulsions.

\begin{tabular}{llcc}
\hline Properties & Specification & CRS-1 & CRS-1S \\
\hline Viscosity Saybolt-Furol (s) & ASTM D7496-17 & 10 & 19 \\
Residue by evaporation (\%) & ASTM D6934-08 & 47.9 & 60.9 \\
Specific mass (g/L) & & 1013.16 & 752.04 \\
\hline
\end{tabular}

\subsection{Impregnation with asphaltic emulsion}

After a characterization of virgin nonwoven geotextiles, a part of samples was sent to a test to measure the capability of geotextile to keep the asphalt material. The impregnation consists of diving the geotextile in an asphalt emulsion sampling, based on ASTM D6140. After saturating geotextiles samples with the binder, they dried in shade until the emulsion setting. This asphalt material does not require heating, allowing to use at room temperature. The working temperature was between 20 and 
$25^{\circ} \mathrm{C}$. The asphalt retention is determined considering the geotextile weight before submerging on asphalt emulsion and after dried. The asphalt retentions for each pair of nonwoven geotextiles to both asphalt emulsions and both production directions are shown in Table 3, with the respective 95\% confidence interval presented in brackets.

Table 3 - Asphalt retention of nonwoven geotextiles according to manufacturing direction.

\begin{tabular}{lllcc}
\hline \multirow{2}{*}{ Nonwoven geotextile } & \multirow{2}{*}{ Asphalt emulsion } & \multicolumn{3}{c}{ Asphalt retention $\left(\mathbf{g} / \mathbf{m}^{2}\right)$} \\
\cline { 3 - 5 } & & MD & XMD & Mean \\
\hline \multirow{2}{*}{ PET } & CRS-1 & $1.69( \pm 0.13)$ & $1.73( \pm 0.07)$ & 1.71 \\
& CRS-1S & $1.44( \pm 0.10)$ & $1.39( \pm 0.18)$ & 1.42 \\
PP & CRS-1 & $1.61( \pm 0.17)$ & $1.45( \pm 0.06)$ & 1.53 \\
& CRS-1S & $1.52( \pm 0.15)$ & $1.48( \pm 0.11)$ & 1.50 \\
\hline
\end{tabular}

MD = machine direction; XMD = cross-machine direction.

\subsection{Damage simulation}

The damage simulation applies a geotextile specimen between two layers of a sintered aggregate (aluminum oxide) to a period of loading. After the simulation, the specimen is subjected to a mechanical or hydraulic test to measure the change on the corresponding property. The percent change between the reference property and the measured after the damage is the result of this test. A reduction factor aims to consider materials' variation on the projects' designing stage.

\subsubsection{Granular materials}

With the purpose to be closer to what is in situ, this study decided to adopt natural materials. The aggregate implemented according to ISO 10722:2007, a sintered aluminum oxide, shall pass a $10 \mathrm{~mm}$ sieve and kept on a $5 \mathrm{~mm}$ sieve. So, the selected gravel has a grain size curve like the sintered aggregate used on the standard. The other two types of granular materials adopted presents different particle sizes faced on base or subbase layers, besides the overlay. All granular materials used on damage simulation grain size curves are presented in Figure 1. While gravel and sand were completely dried, clay presented $21.5 \%$ of humidity and degree of compaction of $88.6 \%$. 
Figure 1 - Particle size distribution of aggregates compared with standard aggregate.

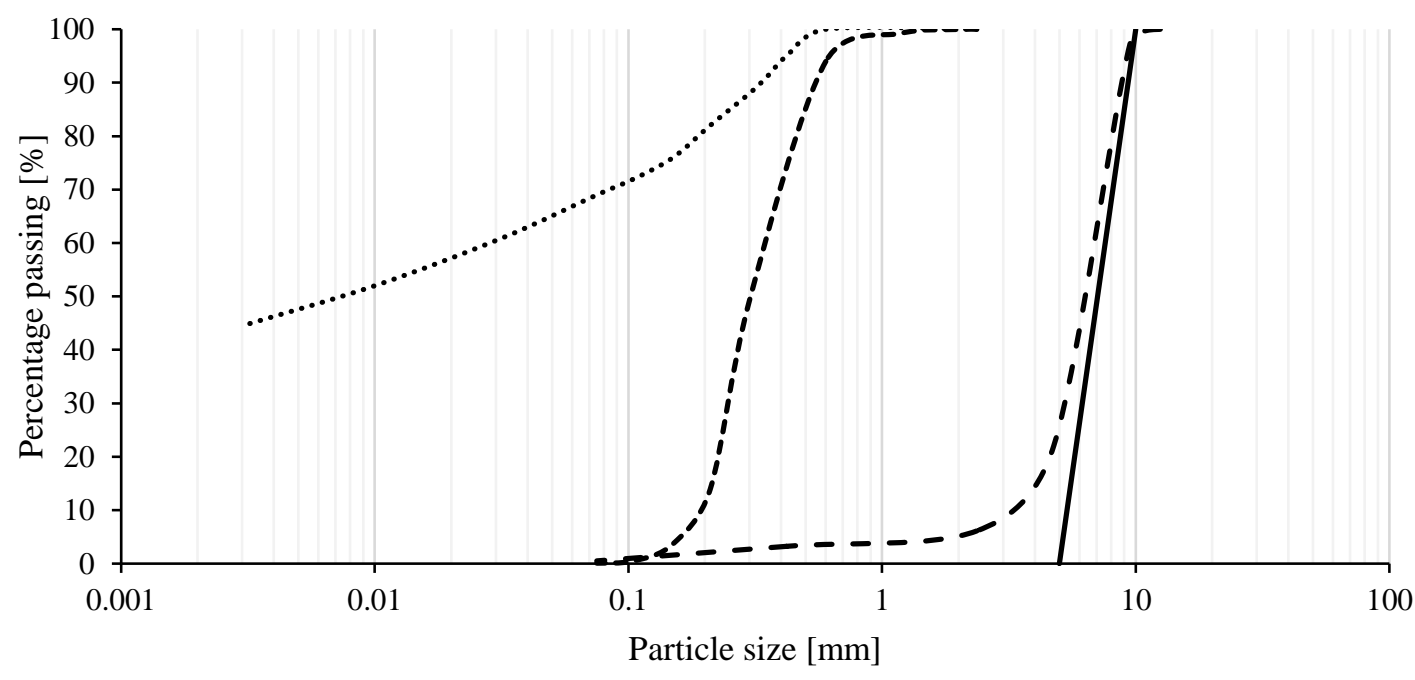

….... Clay - ---Sand - - Gravel $\longrightarrow$ Sintered aggregate

\subsubsection{Load application}

This study applied three load application setups. The first load was cyclic, varying between 10 and $500 \mathrm{kPa}$ with a frequency of $1 \mathrm{~Hz}$ for 200 cycles. The second configuration was a single application of $500 \mathrm{kPa}$ for 60 seconds. The third one was set on a larger closed box with the load application done with a pressure bag, $120 \mathrm{kPa}$ of pressure during $120 \mathrm{~s}$. The not impregnated geotextile samples received damage with all load application settings, while the impregnated samples did not suffer the second load application type. The load setups according to geotextiles and asphalt impregnation are presented in Table 4.

Table 4 - Load application according to geotextile and impregnation.

\begin{tabular}{ccccc}
\hline \multirow{2}{*}{ Nonwoven geotextile } & \multirow{2}{*}{ Impregnation } & \multicolumn{3}{c}{ Load Applications } \\
\cline { 3 - 5 } & Virgin & $\mathrm{X}$ & $\mathrm{X}$ Short static & Long static \\
\hline \multirow{2}{*}{ PET } & CRS-1 & $\mathrm{X}$ & & $\mathrm{X}$ \\
& CRS-1S & $\mathrm{X}$ & & $\mathrm{X}$ \\
& Virgin & $\mathrm{X}$ & $\mathrm{X}$ & $\mathrm{X}$ \\
$\mathrm{TP}$ & CRS-1 & $\mathrm{X}$ & & $\mathrm{X}$ \\
& CRS-1S & $\mathrm{X}$ & $\mathrm{X}$ \\
& & & & $\mathrm{X}$ \\
\hline
\end{tabular}




\subsubsection{Apparatus}

The procedure adopted in this study to run the damage simulation is based on ISO 10722:2007. On the preceding version of this standard in 1998, this procedure was defined as "simulating damage during installation", although in 2007 it was updated to an "evaluation of mechanical damage under repeated loading - damage caused by granular material". The standard requires a rigid metal box with minimal plan dimensions of $300 \mathrm{~mm}$ by $300 \mathrm{~mm}$ with two parts of $75 \mathrm{~mm}$ depth. In this study, the box adopted to run the cyclic and short static load applications present $500 \mathrm{~mm}$ x $500 \mathrm{~mm}$ of plan dimensions with $300 \mathrm{~mm}$ total depth, the load was applicated with a metal plate of $167 \mathrm{~mm}$ by 333 $\mathrm{mm}$ centralized over the top layer of aggregate. While the long static load application runs on a rigid box measuring $1500 \mathrm{~mm}$ by $700 \mathrm{~mm}$ and $150 \mathrm{~mm}$ total depth with a pressure bag placed between the layer of aggregate and the box cover. In the larger box, the three scenarios of impregnation were evaluated at the same time for each geotextile type, while each sample was damaged individually in the smaller box.

\subsubsection{Experimental plan}

There were three groups of nonwoven geotextiles to run the damage simulations: virgin samples (not impregnated), impregnated with CRS-1 and impregnated with CRS-1S. The virgin geotextiles samples were submitted to all setups of load application settings, while the impregnated samples were not submitted to a short static load application. The impregnation procedure for damaged samples followed the method described in 2.3 above. All the impregnated samples were weighed, saturated with asphalt emulsion, dried, weighed after impregnation, and then submitted to the respective damage procedure. The damage test runs three different setups, changing the aggregate type on the bottom layer. After damage tests, five specimens for strength test (strip method) and four specimens for the permeability test were taken from damaged samples. The damage simulation evaluated three varied materials on the bottom layer: gravel, sand, and clay. In the following sections, the damages interfaces will be referred to as GG for gravel on both layers, GS for gravel over 
geotextiles samples and sand under them, and GC for those that had clay on the bottom layer and gravel was on the top.

Figure 2 - Box setups used in damage simulations.

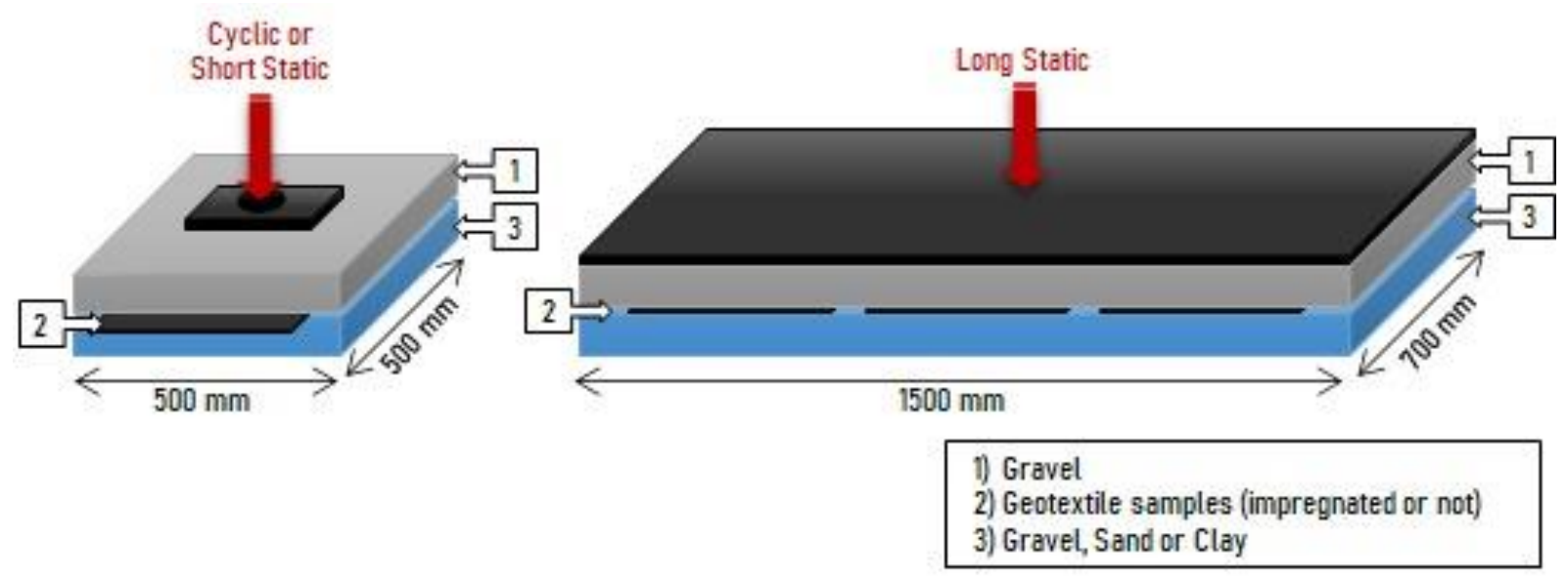

\subsection{Reduction factor for installation damage}

To define the reduction factors and consider the variability of nonwoven geotextiles, an expression $\left(Y_{\text {Norm }}\right)$ considers the mass per unit area of each specimen to normalize the evaluated parameters. As presented in Equation 2, this expression multiplies each specimen parameter $(Y)$ to the relation between nominal mass per unit area of geotextile type $\left(m_{N}\right)$ and the respective mass per unit area of each specimen (m) (Allen, Vinson, \& Bell, 1982).

$$
Y_{\text {Norm }}=\frac{m_{N}}{m} \times Y
$$

The reduction factor for installation damage $\left(R F_{I D}\right)$ is the relation between the maximum parameter supported by virgin material $\left(Y_{\text {und }}\right)$ and the damaged material $\left(Y_{\text {dam }}\right)$ (Pinho-Lopes \& Lopes, 2014). The impregnated damaged samples considered impregnated undamaged samples as reference. So, in this work, calculated reduction factors considered the parameters: maximum tensile strength and stiffness modulus at $2 \%$ strain.

$$
R F_{I D}=\frac{Y_{\text {und }}}{Y_{\text {dam }}}
$$




\section{RESULTS AND DISCUSSION}

According to methods adopted, evaluation of mechanical and hydraulic properties of nonwoven geotextiles happened, considering the amount of asphalt material that geotextile can retain, the change on elongation and tensile strength and the reduction on the permeability of geotextiles. These parameters evaluated reached to comparisons according to the material under geotextile samples and the load application applied over the assembly.

\subsection{Asphalt retention rate}

First, the emulsion viscosity effects directly on how the binder adheres to the geotextiles. Since the emulsion CRS-1S has the SBS polymer as a modifier, it is more fluid than the pure emulsion, so it flows through the geotextile during the drying process. Another parameter that also effects is the geotextile filament structure, considering that both nonwoven geotextiles have the same fabrication method (needled), so PET geotextile keeps more asphaltic emulsion. The mean asphalt retention rates of the samples analyzed in this study are presented in Figure 3 according to the pair of geotextile material and asphaltic emulsion.

\section{Figure 3 - Average asphalt retention rate of samples evaluated.}

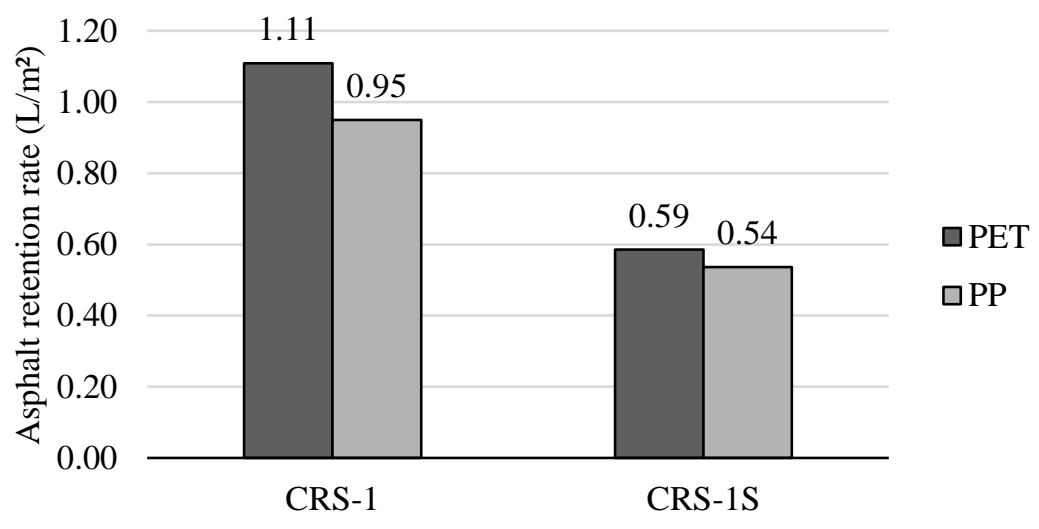

The specific mass of asphalt emulsions explains the difference between the samples impregnated with each asphalt emulsion, as CRS-1 is more condensed presenting a retention rate of two times more the modified CRS-1S. The PET samples also present a retention rate greater than PP, 
it can be explained by the geotextiles heterogeneous structure according to the variation of mass per unit area shown in Table $\mathbf{1}$.

\subsection{Mechanical performance}

After damage simulations, according to ASTM D5035, a test measured the braking force (equivalent to tensile strength) and the elongation for fabrics (equivalent for strain), then applying these results to define the consequent maximum tensile strength, strain at break and stiffness modulus at $2 \%$ of elongation, according to ASTM D4595. Employing the standard method for fabrics (ASTM D5035) allowed a more extensive measurement of properties as each damaged sample supplied five specimens for mechanical analysis.

In this present study, PET-0 and PP-0 represent not impregnated samples, the PET-1 and PP1 are the samples impregnated with CRS-1, and PET-1S and PP-1S had impregnation with CRS-1S, corresponding to each geotextile material. Table 5 presents the results of PET samples as Table 6 presents PP samples values, besides that they present a mean value for each scenario of impregnation not considering short statically (SS) damaged samples. The Tables summarize the mean maximum tensile strength of samples evaluated, the strain at break, and the stiffness modulus at $2 \%$ of elongation, according to load application, interface scenario, and impregnation used. The impregnation enhanced the tensile strength supported by impregnated samples, but the strain at failure decreased as the impregnation increases the stiffness modulus. The PP geotextiles presented higher tensile strength than PET overall.

Analyzing the Table 5 with PET results, the impregnation on average decreased $13.4 \%$ of the elongation, while this process improved $65 \%$ of the maximum tensile strength and $499 \%$ the stiffness modulus at $2 \%$ of elongation. The asphalt emulsion CRS-1 had a more positive impact than CRS-1S; thus the enhancement on tensile strength were $76.5 \%$ and $54.0 \%$, on the maximum elongation were a loss of $15.5 \%$ and $11.4 \%$, and a more noteworthy improvement on stiffness modulus of $524.2 \%$ and $474.3 \%$, respectively for each type of asphalt emulsion. 
Evaluating the variability (coefficient of variation), PET samples presented values for tensile strength and elongation less than $10 \%$. The stiffness presents higher values for the coefficient of variation, as both strain and strength influence on this parameter.

Table 5 - PET tensile properties results.

\begin{tabular}{lllcccccc}
\hline Material & Load application $^{\text {a }}$ & Interface & $\begin{array}{c}\boldsymbol{\tau}_{\max } \\
(\mathbf{k N} / \mathbf{m})\end{array}$ & $\begin{array}{c}\mathbf{C V} \\
(\boldsymbol{\%})\end{array}$ & $\begin{array}{c}\boldsymbol{\varepsilon} \\
(\boldsymbol{\%})\end{array}$ & $\begin{array}{c}\mathbf{C V} \\
(\boldsymbol{\%})\end{array}$ & $\begin{array}{c}\boldsymbol{J}_{\mathbf{2}} \% \\
(\mathbf{k N / m})\end{array}$ & $\begin{array}{c}\mathbf{C V} \\
(\boldsymbol{\%})\end{array}$ \\
\hline PET-0 & Undamaged & & 5.47 & 13.86 & 59.71 & 2.49 & 5.77 & 16.11 \\
& CC & G-G & 4.52 & 9.89 & 42.65 & 5.48 & 22.10 & 13.95 \\
& CC & G-S & 5.29 & 5.99 & 40.87 & 4.45 & 32.54 & 5.70 \\
& CC & G-C & 4.57 & 6.82 & 38.22 & 16.24 & 14.78 & 43.03 \\
& LS & G-G & 5.18 & 7.98 & 43.10 & 5.54 & 7.94 & 40.00 \\
& LS & G-S & 5.09 & 4.91 & 44.95 & 4.43 & 6.94 & 30.64 \\
& LS & G-C & 4.92 & 7.33 & 50.19 & 7.89 & 5.99 & 69.72 \\
& SS & G-G & 4.96 & 3.47 & 37.86 & 8.81 & 23.80 & 13.18 \\
& SS & G-S & 4.76 & 2.66 & 44.31 & 7.80 & 15.75 & 12.46 \\
& SS & G-C & 5.44 & 9.72 & 39.02 & 7.22 & 14.46 & 26.06 \\
& Mean & & 5.01 & 8.11 & 45.67 & 6.65 & 13.72 & 31.31 \\
\hline PET-1 & Undamaged & & 9.15 & 8.62 & 47.87 & 4.55 & 90.06 & 7.51 \\
& CC & G-G & 8.43 & 4.41 & 31.43 & 28.17 & 87.53 & 7.27 \\
& CC & G-S & 8.37 & 5.93 & 32.53 & 7.44 & 92.68 & 14.79 \\
& CC & G-C & 8.99 & 3.36 & 34.41 & 6.26 & 90.38 & 21.25 \\
& LS & G-G & 8.50 & 5.89 & 38.55 & 4.42 & 85.46 & 9.55 \\
& LS & G-S & 9.18 & 2.62 & 43.81 & 5.45 & 68.21 & 39.87 \\
& LS & G-C & 9.22 & 2.89 & 41.70 & 4.57 & 85.29 & 14.84 \\
& Mean & & 8.83 & 4.82 & 38.61 & 8.70 & 85.66 & 16.44 \\
\hline PET-1S & Undamaged & & 7.41 & 8.19 & 47.36 & 4.23 & 58.92 & 10.21 \\
& CC & G-G & 7.65 & 3.30 & 39.68 & 4.08 & 123.96 & 3.88 \\
& CC & G-S & 7.69 & 2.06 & 35.63 & 5.00 & 81.86 & 9.36 \\
& CC & G-C & 7.97 & 3.74 & 31.37 & 6.24 & 80.28 & 12.28 \\
& LS & G-G & 7.20 & 6.16 & 40.25 & 6.41 & 66.07 & 6.59 \\
& LS & G-S & 7.93 & 7.21 & 43.16 & 7.76 & 70.33 & 8.84 \\
& LS & G-C & 8.10 & 6.03 & 45.88 & 9.20 & 70.27 & 10.47 \\
& Mean & & 7.71 & 5.24 & 40.48 & 6.13 & 78.81 & 8.80 \\
\hline
\end{tabular}

${ }^{\mathrm{a}}$ Load application: $\mathrm{CC}=$ cyclic; $\mathrm{SS}=$ short static; $\mathrm{LS}=$ long static. ${ }^{\mathrm{b}}$ Mean value did not consider SS.

With the results of PP samples (Table 6), the impregnation enhanced the tensile strength on $48 \%$ and the stiffness modulus on $683 \%$, but the elongation decreased $35 \%$ on its capacity. As explained for PET samples before, CRS-1 had more benefits for geotextiles than CRS-1S, about 14.2\%. The values for geotextiles impregnated with CRS-1 enhanced $53.8 \%$ on tensile strength, $699.5 \%$ on stiffness modulus, and decreased $33.6 \%$ on elongation at failure, while samples 
impregnated with CRS-1S presented, respectively, an improvement of $42.0 \%$ and $667.0 \%$ on tensile strength and stiffness modulus at $2 \%$ of elongation, and $36.8 \%$ of loss on strain at failure.

As noted on the values presented, PP samples had more variability than PET samples. The stiffness modulus at $2 \%$ of elongation continues presenting higher values of coefficient of variation, as these mean values have the consistency of means around $10 \%$ and the stiffness has a bigger variability of coefficients also.

Table 6 - PP tensile properties results.

\begin{tabular}{|c|c|c|c|c|c|c|c|c|}
\hline Material & Load application a & Interface & $\tau_{(\mathbf{k N a x} / \mathbf{m})}$ & $\begin{array}{l}\text { CV } \\
(\%)\end{array}$ & $\begin{array}{c}\varepsilon \\
(\%)\end{array}$ & $\begin{array}{l}\text { CV } \\
(\%)\end{array}$ & $\begin{array}{c}\boldsymbol{J}_{\mathbf{2} \%} \\
(\mathbf{k N} / \mathbf{m})\end{array}$ & $\begin{array}{l}\text { CV } \\
(\%)\end{array}$ \\
\hline \multirow[t]{11}{*}{ PP-0 } & Undamaged & & 6.14 & 11.62 & 75.84 & 8.30 & 5.43 & 26.15 \\
\hline & $\mathrm{CC}$ & G-G & 6.64 & 2.77 & 48.63 & 4.88 & 16.77 & 11.36 \\
\hline & $\mathrm{CC}$ & G-S & 6.25 & 18.55 & 60.39 & 5.63 & 6.98 & 17.68 \\
\hline & $\mathrm{CC}$ & G-C & 7.02 & 13.84 & 63.30 & 6.71 & 8.66 & 22.83 \\
\hline & $\mathrm{LS}$ & $\mathrm{G}-\mathrm{G}$ & 7.11 & 3.18 & 49.88 & 4.70 & 5.84 & 12.44 \\
\hline & LS & G-S & 7.66 & 13.64 & 45.22 & 5.94 & 6.48 & 22.83 \\
\hline & LS & G-C & 8.67 & 8.39 & 95.55 & 5.70 & 4.87 & 35.35 \\
\hline & SS & G-G & 7.70 & 18.87 & 42.69 & 17.42 & 20.03 & 22.86 \\
\hline & SS & $\mathrm{G}-\mathrm{S}$ & 7.67 & 6.71 & 43.61 & 4.64 & 10.10 & 48.44 \\
\hline & SS & G-C & 7.43 & 15.42 & 51.24 & 11.39 & 10.38 & 42.22 \\
\hline & Mean $^{b}$ & & 7.07 & 10.28 & 62.69 & 5.98 & 7.86 & 21.24 \\
\hline \multirow[t]{8}{*}{ PP-1 } & Undamaged & & 10.97 & 14.99 & 40.08 & 17.68 & 60.17 & 20.14 \\
\hline & $\mathrm{CC}$ & G-G & 10.21 & 5.76 & 38.12 & 7.22 & 63.11 & 8.26 \\
\hline & $\mathrm{CC}$ & G-S & 10.22 & 8.84 & 38.10 & 6.14 & 62.09 & 14.01 \\
\hline & $\mathrm{CC}$ & G-C & 10.86 & 14.47 & 35.78 & 12.14 & 67.52 & 12.57 \\
\hline & LS & $\mathrm{G}-\mathrm{G}$ & 11.51 & 8.72 & 49.10 & 6.65 & 66.13 & 11.72 \\
\hline & LS & G-S & 11.94 & 7.13 & 49.56 & 4.04 & 60.32 & 6.21 \\
\hline & LS & G-C & 10.39 & 16.06 & 40.71 & 13.27 & 60.61 & 10.95 \\
\hline & Mean & & 10.87 & 10.85 & 41.64 & 9.59 & 62.85 & 11.98 \\
\hline \multirow[t]{8}{*}{ PP-1S } & Undamaged & & 9.25 & 11.41 & 38.37 & 16.11 & 56.91 & 14.74 \\
\hline & $\mathrm{CC}$ & G-G & 10.11 & 12.73 & 34.83 & 13.20 & 74.87 & 8.89 \\
\hline & $\mathrm{CC}$ & $\mathrm{G}-\mathrm{S}$ & 9.79 & 16.60 & 38.09 & 17.41 & 59.48 & 23.72 \\
\hline & $\mathrm{CC}$ & G-C & 11.09 & 11.49 & 37.23 & 11.03 & 68.14 & 5.05 \\
\hline & LS & $\mathrm{G}-\mathrm{G}$ & 9.47 & 7.45 & 43.76 & 6.75 & 50.24 & 10.11 \\
\hline & LS & G-S & 10.15 & 19.76 & 43.91 & 12.63 & 59.25 & 18.78 \\
\hline & LS & G-C & 10.41 & 14.32 & 40.95 & 7.97 & 53.21 & 28.83 \\
\hline & Mean & & 10.04 & 13.39 & 39.59 & 12.16 & 60.30 & 15.73 \\
\hline
\end{tabular}

${ }^{\mathrm{a}}$ Load application: $\mathrm{CC}=$ cyclic; $\mathrm{SS}=$ short static; $\mathbf{L S}=$ long static. ${ }^{\mathrm{b}}$ Mean value did not consider $\mathrm{SS}$.

\subsection{Hydraulic performance}

The ASTM D4491 determines the procedure to measure the flow that each specimen is capable to conduct on its section area. The permeability is the product of the permittivity value and 
the specimen thickness, this study chose to compare the permittivity parameter as the specimens have high thickness' variability. The results for permittivity tests are summarized by the mean of four specimens from each sample for all scenarios in Table 7, with the respective coefficient of variation in brackets. Geotextiles not impregnated present higher permittivity; on average the impregnation reduced more than $50 \%$ of permittivity parameter. Although, the damage simulations did not present significant variation in impregnated samples, on average.

Table 7 - Permittivity $\left(\mathrm{s}^{-1}\right)$ of all samples evaluated.

\begin{tabular}{cccccccc}
\hline $\begin{array}{c}\text { Load } \\
\text { application }\end{array}$ & Interface & PET-0 & PET-1 & PET-1S & PP-0 & PP-1 & PP-1S \\
\hline Undamaged & & $5.29(8.26)$ & $1.37(2.14)$ & $1.13(1.76)$ & $2.37(4.48)$ & $0.70(1.32)$ & $1.80(3.41)$ \\
CC & G-G & $4.26(6.66)$ & $1.46(2.28)$ & $0.65(1.02)$ & $5.21(9.87)$ & $1.24(2.34)$ & $1.46(2.77)$ \\
CC & G-S & $4.72(7.38)$ & $0.68(1.07)$ & $1.20(1.87)$ & $5.17(9.79)$ & $0.91(1.73)$ & $2.08(3.95)$ \\
CC & G-C & $4.23(6.61)$ & $1.29(2.01)$ & $1.49(2.33)$ & $4.60(8.71)$ & $0.81(1.54)$ & $1.74(3.29)$ \\
LS & G-G & $4.10(6.40)$ & $1.30(2.03)$ & $1.96(3.06)$ & $2.42(4.59)$ & $1.37(2.59)$ & $1.83(3.46)$ \\
LS & G-S & $4.62(7.21)$ & $1.22(1.90)$ & $1.74(2.71)$ & $2.32(4.39)$ & $2.83(5.36)$ & $2.08(3.95)$ \\
LS & G-C & $4.41(6.89)$ & $0.05(0.07)$ & $1.77(2.76)$ & $8.89(16.83)$ & $2.82(5.34)$ & $1.91(3.62)$ \\
SS & G-G & $4.34(6.78)$ & & & $3.07(5.82)$ & & \\
SS & G-S & $4.90(7.65)$ & & & $2.88(5.46)$ & & \\
SS & G-C & $3.91(6.11)$ & & & $2.55(4.83)$ & & \\
\hline
\end{tabular}

a Load application: $\mathrm{CC}=$ cyclic; $\mathrm{SS}=$ short static; $\mathrm{LS}=$ long static. Coefficient of variation (\%) presented in brackets.

From Table 7 comparing all the scenarios, virgin materials present higher permittivity than impregnated samples. Also, impregnating the samples with CRS-1 significantly reduces the permeability of the materials, more clear analyzing PET geotextiles results. Asphalt emulsions specific mass explain the difference between the permeabilities for CRS-1 and CRS-1S as it shows the quantity of asphaltic material contained on the binder.

PET geotextile samples had a reduction of permittivity after damage simulations (5\% on average), but PP samples presented better permittivity, an improvement of $71 \%$ on average. The damage decreased by $19 \%$ the permittivity of PET not impregnated samples, and on $27 \%$ on 
impregnated with CRS-1, but the impregnated with CRS-1S samples increased by $30 \%$ on average. The PP not impregnated damaged samples increased the permittivity on $74 \%$ on average, although, when not considering the virgin sample long-statically damaged this average decrease to $49 \%$. Both impregnation types enhanced the permittivity of PP samples, the asphalt emulsion CRS-1S improved by $3 \%$ while CRS-1 by $137 \%$.

\subsection{Influence of material used on the lower layer}

The three types of aggregates used on the bottom layer in damage simulations reached to different findings. The simulation of damage presents a break of geotextiles' filaments, directly meaning a damage on the geotextiles' structure. It was expected a bigger loss of mechanical values with simulation with the use of granular materials of bigger diameter. So, the comparisons consider the values obtained for each type of load application to better visualize the effect on the different interfaces.

On Figure 4, the tensile parameters are compared according the interface of damage as the solid series represents the values of reference from undamaged samples. The comparison considers each type of load application presenting respectively the cyclic, long static, and short static results. Analyzing the maximum tensile strength results, it is hard to see a tendency on the results, but a regularity of results. By contrast with expectations, some results of damaged samples presented higher tensile strength values than undamaged samples. 
Figure 4 - Effect of interface on tensile parameters.

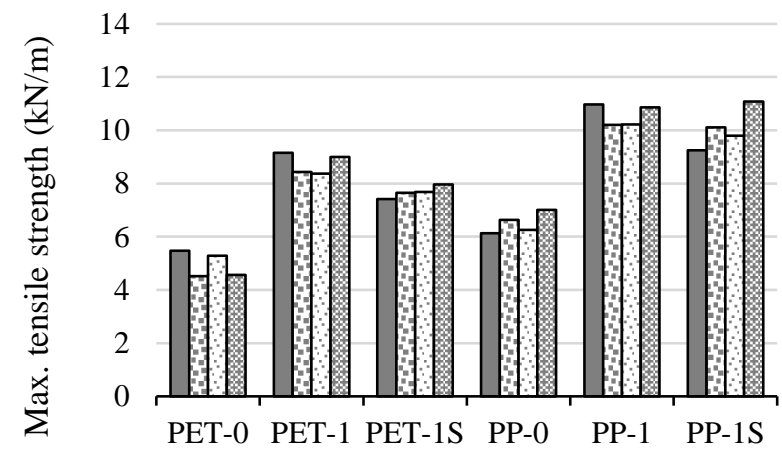

CC

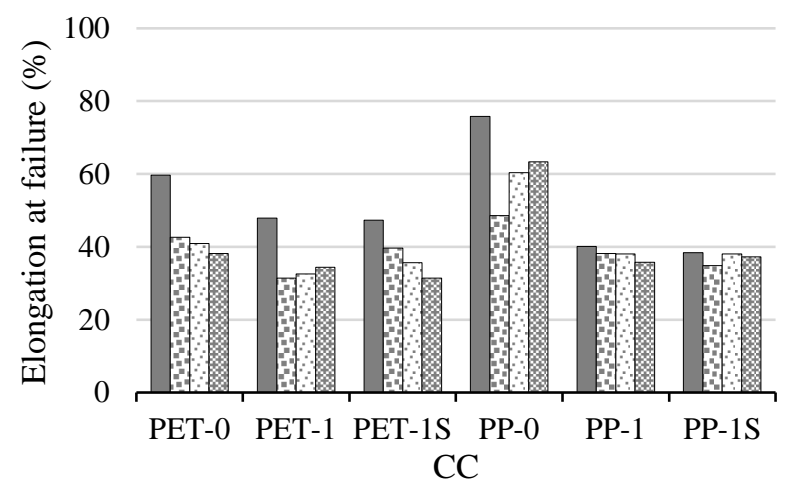

CC

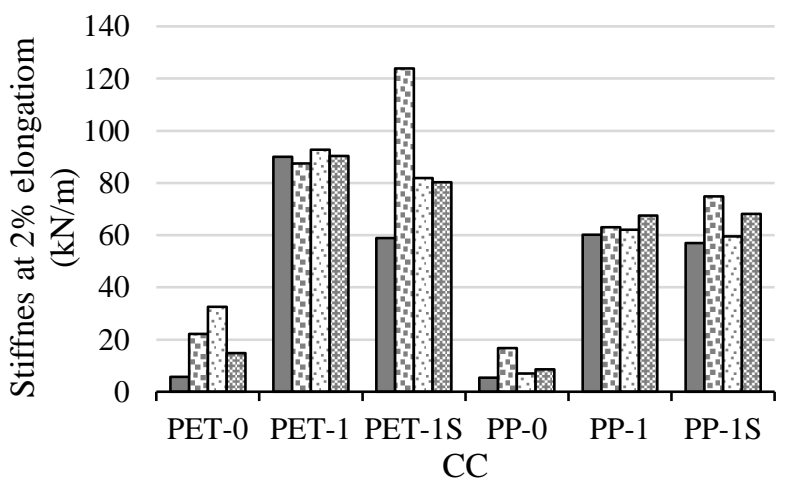

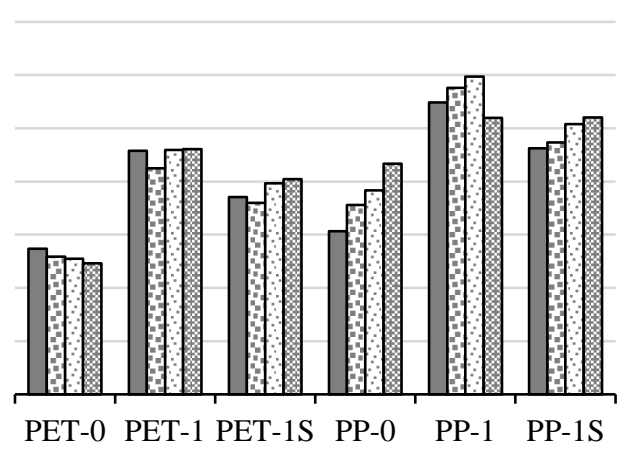

LS
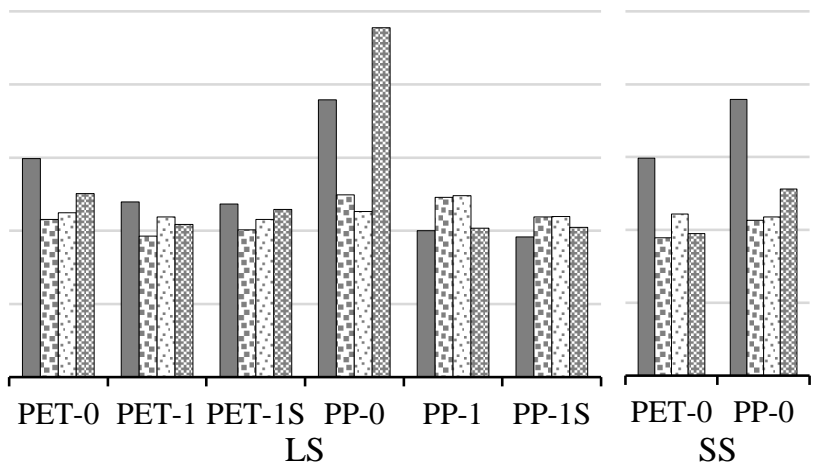

LS

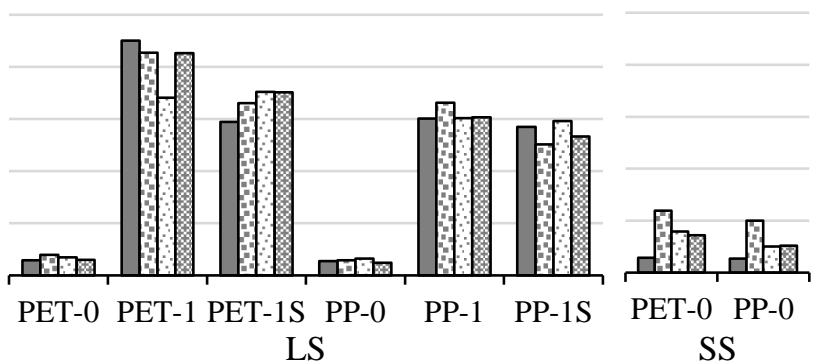

\section{Load application: $\mathrm{CC}=$ cyclic, $\mathrm{LS}=$ long static, $\mathrm{SS}=$ short static .}

Disregarding the maximum tensile strength and seeing the maximum elongation supported, the damaged samples show a loss on this property when comparing to undamaged samples. All samples presented loss of their capability of elongation, not only the impregnation decreases the geotextiles elongation, but also the damage effects on elongation. One exception is the sample not 
impregnated of polypropylene (PP-0) damaged over a clay layer (G-C), that had an increase of $26 \%$ on this parameter.

Expected to present the bigger impact, the interface with gravel on both layers caused a damage like other two interfaces (gravel-sand and gravel-clay), on average. The clay compacted used on the bottom layer presented a higher impact on geotextiles' performance around 5\% more loss on properties than the gravel-gravel scenario. The angularity of gravel and high stiffness of compacted clay may explain that behavior, so the bottom layer tends to damage the geotextile placed over the layer with load applications.

\subsection{Influence of load application type}

Still considering the Figure 4, the expectations were to have more significant damage on simulations that run cyclic load applications, followed by long static load application, and lastly the short static. Three load applications over the assembly promoted a comparison to (maybe) change the method to shorter tests. Although, the results obtained on damage simulations do not lead to a tendency as the load applications have varied. Cyclic simulation did run the higher loss of properties, but it had some exceptions. Overall, the different load applications did not represent a significant damage to nonwoven geotextiles, but they showed a high variability of geotextiles samples.

\subsection{Reduction factors for tensile properties}

Considering that this study evaluated materials applied in flexible pavements, it is necessary to consider how geotextiles' tensile modulus differs from other materials placed on layers above and under the geosynthetics. This comparison evaluated the stiffness modulus of all scenarios at $2 \%$ of elongation calculated according to ASTM D4595. It allows a comparison of how the impregnation improves stiffness for nonwoven geotextiles, as the range of pavement deformations are tight. As shown in Figure 5, the impregnation grants high stiffness modulus for nonwoven geotextiles. Impregnated samples present greater modulus than virgin samples, even after damage tests comparing to undamaged nonwoven geotextile. Evaluating not impregnated geotextiles, PET presents higher 
stiffness. The impregnated samples of both geotextile materials present similar behavior, although PET presents higher stiffness modulus as PP is a material with a more constant reduction of stiffness. The type of emulsion asphalt used to impregnate the geotextile influences that much on geotextile stiffness, but CRS-1 presents better improvement than CRS-1S.

\section{Figure 5 - Mean stiffness modulus at $2 \%$ strain according to geotextile and impregnation.}

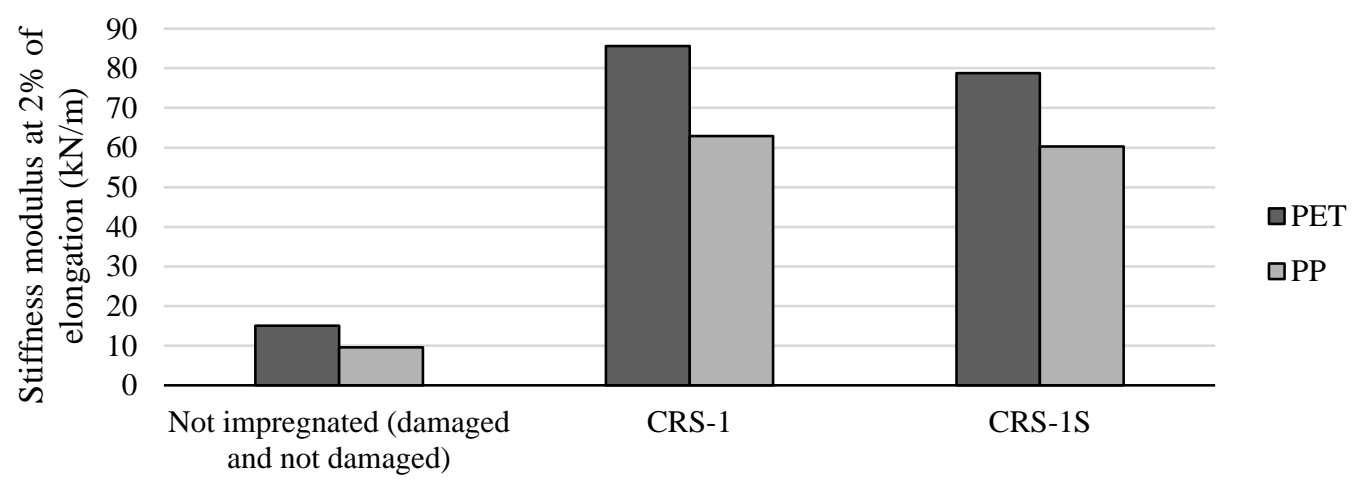

The correspondent reduction factor quantifies the difference between the properties of damaged and undamaged samples. As this analysis considers undamaged samples as reference, the damaged impregnated samples used undamaged impregnated samples to compare their variation. The reduction factors are the inverse of residual property. The reduction factors, presented on Table 8, considered the three parameters measured: tensile strength, elongation, and stiffness at $2 \%$ of strain. The minimum value acceptable for the reduction factor is 1.00 and values in the range of $95 \%$ of confidence level were adjusted to 1.00 also, so reduction factors lower than this value the designing should consider the value as 1.00 .

Considering the high variability of geotextiles, the damage caused by granular materials next to the geosynthetics are not considerable, while the impregnation shows a more significant effect. 
Table 8 - Reduction factors for tensile properties of all scenarios evaluated.

\begin{tabular}{|c|c|c|c|c|c|c|c|c|}
\hline \multirow{2}{*}{ Impregnation } & \multirow{2}{*}{$\begin{array}{l}\text { Load } \\
\text { Config. }\end{array}$} & \multirow{2}{*}{ Interface } & \multicolumn{3}{|c|}{ PET } & \multicolumn{3}{|c|}{ PP } \\
\hline & & & Tensile & Elongation & Stiffness & Tensile & Elongation & Stiffness \\
\hline \multirow[t]{10}{*}{00} & Undamaged & & 1.00 & 1.00 & 1.00 & 1.00 & 1.00 & 1.00 \\
\hline & $\mathrm{CC}$ & G-G & 1.21 & 1.40 & 0.26 & 0.92 & 1.56 & 0.32 \\
\hline & $\mathrm{CC}$ & G-S & 1.00 & 1.46 & 0.18 & 0.98 & 1.26 & 1.00 \\
\hline & $\mathrm{CC}$ & G-C & 1.20 & 1.56 & 0.39 & 0.87 & 1.20 & 0.63 \\
\hline & LS & G-G & 1.00 & 1.39 & 0.73 & 0.86 & 1.52 & 1.00 \\
\hline & LS & G-S & 1.00 & 1.33 & 0.83 & 0.80 & 1.68 & 1.00 \\
\hline & LS & G-C & 1.00 & 1.19 & 1.00 & 0.71 & 0.79 & 1.00 \\
\hline & SS & G-G & 1.00 & 1.58 & 0.24 & 0.80 & 1.78 & 0.27 \\
\hline & SS & G-S & 1.15 & 1.35 & 0.37 & 0.80 & 1.74 & 0.54 \\
\hline & $\mathrm{SS}$ & $\mathrm{G}-\mathrm{C}$ & 1.00 & 1.53 & 0.40 & 0.83 & 1.48 & 0.52 \\
\hline \multirow[t]{7}{*}{$C R S-1$} & Undamaged & & 1.00 & 1.00 & 1.00 & 1.00 & 1.00 & 1.00 \\
\hline & $\mathrm{CC}$ & G-G & 1.00 & 1.52 & 1.00 & 1.07 & 1.00 & 1.00 \\
\hline & $\mathrm{CC}$ & G-S & 1.00 & 1.47 & 1.00 & 1.07 & 1.00 & 1.00 \\
\hline & $\mathrm{CC}$ & G-C & 1.00 & 1.39 & 1.00 & 1.00 & 1.00 & 1.00 \\
\hline & LS & G-G & 1.00 & 1.24 & 1.00 & 1.00 & 1.00 & 1.00 \\
\hline & LS & G-S & 1.00 & 1.09 & 1.32 & 1.00 & 1.00 & 1.00 \\
\hline & LS & G-C & 1.00 & 1.15 & 1.00 & 1.06 & 1.00 & 1.00 \\
\hline \multirow[t]{7}{*}{$C R S-1 S$} & Undamaged & & 1.00 & 1.00 & 1.00 & 1.00 & 1.00 & 1.00 \\
\hline & $\mathrm{CC}$ & G-G & 1.00 & 1.19 & 0.48 & 1.00 & 1.10 & 1.00 \\
\hline & $\mathrm{CC}$ & G-S & 1.00 & 1.33 & 0.72 & 1.00 & 1.00 & 1.00 \\
\hline & $\mathrm{CC}$ & G-C & 1.00 & 1.51 & 0.73 & 1.00 & 1.00 & 1.00 \\
\hline & LS & G-G & 1.00 & 1.18 & 1.00 & 1.00 & 1.00 & 1.13 \\
\hline & LS & G-S & 1.00 & 1.10 & 0.84 & 1.00 & 1.00 & 1.00 \\
\hline & LS & G-C & 1.00 & 1.03 & 1.00 & 1.00 & 1.00 & 1.07 \\
\hline
\end{tabular}

Load application: $\mathrm{CC}=$ cyclic; $\mathrm{LS}=$ long static; $\mathrm{SS}=$ short static.

\section{CONCLUSIONS}

The materials applied around nonwoven geotextiles used on paving have high significance on the damage suffered by these geosynthetics. The variation of properties before and after damage simulation quantifies the damage. Greater damage occurs during installation as big equipment run directly over the geotextile, affecting on its performance, even when impregnated with asphalt materials. Although, early considered as damage during installation, the damage caused by granular materials did not seem to be a test to measure the loss on the mechanical performance for nonwoven geotextiles. Considering the parameters evaluated in this study, the results support these following conclusions: 
- Nonwoven geotextiles present high variability as the manufacturing process is not regular. This characteristic interferes directly their physical or mechanical parameters as thickness, asphalt retention, strain at break, and others.

- The impregnation process improves the mechanical performance of nonwoven geotextiles. The maximum tensile strength enhanced about 52\% compared to not impregnated geotextiles. It must be clear that even with this high improvement on mechanical characteristics, the function of paving reinforcement means service on low displacement range. So, it is more significant a comparison of the stiffness modulus at $2 \%$ of total strain. By this parameter, the impregnation increased the performance of geotextiles presenting values about 5 times of not impregnated samples, considering both geo-materials and asphalt emulsions.

- From both asphalt emulsions evaluated, the modified asphalt emulsion CRS-1S performs better results only for stiffness with more than $10 \%$ of elongation, where deflections at this level means that the pavement is already damaged. So, the emulsion asphalt CRS-1 has more successful results for the application of geotextiles to paving projects as it brings the benefits of asphalt binder more concentrated to geosynthetics.

- The damage simulated, even with different load applications, did not show a significant loss on properties of nonwoven geotextiles. The high variability of this type of geosynthetic hides the damages caused by the break of geotextile filaments. New filaments created continue being part of geotextile structure and not breaking the geotextile itself.

- Analyzing the hydraulic performance of geotextiles, the damage does not affect with a tendency. There are two potential causes to the effect of the damage: a rearrangement of filaments due to the break and a deposition of sediments of granular materials on geotextile's structure. As the main function of geotextile applied on paving is to reinforce 
the pavement, the designing does not consider the permittivity changes caused by damage and impregnation on paving techniques.

\section{ACKNOWLEDGEMENTS}

This study thanks the National Council for Scientific and Technological Development (CNPq) and the University of São Paulo for the financial support.

\section{REFERENCES}

Allen, T., Vinson, T. S., \& Bell, J. R. (1982). Tensile strength and creep behaviour of geotextiles in cold regions applications. In Second International Conference on Geotextiles (pp. 775-780). Las Vegas, USA.

ASTM. (1992). D4491-99 - Standard test method for water permeability of geotextiles by permittivity. ASTM Standards. https://doi.org/10.1520/D4491

ASTM (2012). D4354-12 - Standard Practice for Sampling of Geosynthetics and Rolled Erosion Control Products (RECPs) for Testing. https://doi.org/10.1520/D4354-12

ASTM. (2012). D5199 - Standard Test Method for Measuring the Nominal Thickness of Geosynthetics. https://doi.org/10.1520/D5199-01R06.2

ASTM. (2014). D6140 - Standard Test Method to Determine Asphalt Retention of Paving Fabrics Used in Asphalt Paving for Full-Width Applications. https://doi.org/10.1520/D6140-00R09.2

ASTM. (2015). D5035 - Standard Test Method for Breaking Force and Elongation of Textile Fabrics (Strip Method). https://doi.org/10.1520/D5034-09R13.2

ASTM. (2016). D6934 - Standard Test Method for Residue by Evaporation of Emulsified Asphalt. https://doi.org/10.1520/D6934-08R16.2

ASTM. (2017). D4595 - Standard Test Method for Tensile Properties of Geotextiles by the WideWidth Strip Method. https://doi.org/10.1520/D4595-17. 
ASTM. (2017). D7496-17 - Standard Test Method for Viscosity of Emulsified Asphalt by Saybolt Furol Viscometer. https://doi.org/10.1520/D7496-17.

ASTM. (2018). D5261 - Standard Test Method for Measuring Mass per Unit Area of Geotextiles. https://doi.org/10.1520/D4833-07.2

Cleveland, G. S., Button, J. W., \& Lytton, R. L. (2002). Geosynthetics in Flexible and Rigid Pavement Overlay System to Reduce Reflection Cracking. Austin, TX. Retrieved from https://static.tti.tamu.edu/tti.tamu.edu/documents/1777-1.pdf

Correia, N. S., \& Zornberg, J. G. (2014). Influence of tack coat rate on the properties of paving geosynthetics. Transportation $\quad$ Geotechnics, $\quad 1(1), \quad$ 45-54. https://doi.org/10.1016/j.trgeo.2014.01.002

Correia, N. S., \& Zornberg, J. G. (2016). Mechanical response of flexible pavements enhanced with geogrid-reinforced asphalt overlays. Geosynthetics International, 23(3), 183-193. https://doi.org/10.1680/jgein.15.00041

Correia, N. S., \& Zornberg, J. G. (2018). Strain distribution along geogrid-reinforced asphalt overlays under traffic loading. Geotextiles and Geomembranes, 46(1), 111-120. https://doi.org/10.1016/J.GEOTEXMEM.2017.10.002

Dhakal, N., Elseifi, M. A., \& Zhang, Z. (2016). Mitigation strategies for reflection cracking in rehabilitated pavements - A synthesis. International Journal of Pavement Research and Technology, 9(3), 228-239. https://doi.org/10.1016/J.IJPRT.2016.05.001

Dias, M., Carneiro, J. R., \& Lopes, M. de L. (2017). Resistance of a nonwoven geotextile against mechanical damage and abrasion. Ciencia e Tecnologia Dos Materiais, 29(1), e177-e181. https://doi.org/10.1016/j.ctmat.2016.07.007

Fallah, S., \& Khodaii, A. (2015). Reinforcing overlay to reduce reflection cracking; an experimental investigation. Geotextiles and Geomembranes, 43(3), 216-227. https://doi.org/10.1016/J.GEOTEXMEM.2015.03.002 
Gonzalez-Torre, I., Calzada-Perez, M. A., Vega-Zamanillo, A., \& Castro-Fresno, D. (2014). Damage evaluation during installation of geosynthetics used in asphalt pavements. Geosynthetics International, 21(6), 377-386. https://doi.org/10.1680/gein.14.00025

Hufenus, R., Rüegger, R., Flum, D., \& Sterba, I. J. (2005). Strength reduction factors due to installation damage of reinforcing geosynthetics. Geotextiles and Geomembranes, 23(5), 401424. https://doi.org/10.1016/J.GEOTEXMEM.2005.02.003

ISO. (2007). ISO 10722 - Geosynthetics - Index test procedure for the evaluation of mechanical damage under repeated loading - Damage caused by granular material.

Khodaii, A., Fallah, S., \& Nejad, F. M. (2008). Effects of geosynthetics on reduction of reflection cracking in asphalt overlays. Geotextiles and Geomembranes, 27(1), 1-8. https://doi.org/10.1016/j.geotexmem.2008.05.007

Koerner, R. M. (2005). Designing with geotextiles. In Designing with geosynthetics (5th ed., pp. 79327). Upper Saddle River, NJ: Prentice Hall.

Norambuena-Contreras, J., \& Gonzalez-Torre, I. (2015). Influence of geosynthetic type on retarding cracking in asphalt pavements. Construction and Building Materials, 78, 421-429. https://doi.org/10.1016/J.CONBUILDMAT.2014.12.034

Norambuena-Contreras, J., Gonzalez-Torre, I., Fernandez-Arnau, D., \& Lopez-Riveros, C. (2016). Mechanical damage evaluation of geosynthetics fibres used as anti-reflective cracking systems in asphalt pavements. Construction and Building Materials, 109, 47-54. https://doi.org/10.1016/j.conbuildmat.2016.01.057

Paula, A. M., Silvano, R. P., Pinho-Lopes, M., \& Lopes, M. de L. (2004). Danificação durante a instalação de geotêxteis não tecidos: análise laboratorial da influência do tipo de material granular e da energia de compactação. In II Congresso Luso-Brasileiro de Geotecnia (pp. 239248). Aveiro. Retrieved from http://hdl.handle.net/10198/1773

Pinho-Lopes, M., \& Lopes, M. de L. (2014). Tensile properties of geosynthetics after installation 
damage. Environmental Geotechnics, 1, 161-178. https://doi.org/10.1680/envgeo.13.00032

Vilchez, G. E. M. (2002). Contribuição para a elaboração de método de projeto de restauração de pavimentos asfálticos utilizando geossintéticos em sistemas anti-reflexão de trincas. Instituto Tecnológico da Aeronáutica.

Wang, J., Xiao, F., Chen, Z., Li, X., \& Amirkhanian, S. (2017). Application of tack coat in pavement engineering. Construction and Building Materials, 152, 856-871. https://doi.org/10.1016/j.conbuildmat.2017.07.056

Zamora-Barraza, D., Calzada-Pérez, M. A., Castro-Fresno, D., \& Vega-Zamanillo, A. (2011). Evaluation of anti-reflective cracking systems using geosynthetics in the interlayer zone. Geotextiles and Geomembranes, 29(2), 130-136. https://doi.org/10.1016/J.GEOTEXMEM.2010.10.005

Zornberg, J. G. (2012). Geosynthetic-reinforced Pavement Systems. In Fifth European Geosynthetics Conference, EuroGeo5 (pp. 49-61). Valencia, Spain: Keynote Lectures Volume. Retrieved from www.eurogeo5.org 